\title{
Mancha-de-Cercospora em Melancia no Estado de Roraima
}

\author{
Bernardo A. Halfeld-Vieira, Kátia de L. Nechet \& Paulo Roberto V. S. Pereira \\ Embrapa Roraima, BR 174, km 08, Cx. Postal 133, CEP 69301-970, Boa Vista, RR, e-mail: halfeld@ cpafrr.embrapa.br
}

(Aceito para publicação em 04/12/2003)

Autor para correspondência: Bernardo A. Halfeld-Vieira

\begin{abstract}
Cercopsora leaf spot in watermelon at the State of Roraima

Cercospora leaf spot in Citrullus lanatus caused by Cercospora citrullina is first reported in Roraima, Brazil.
\end{abstract}

A melancia [Citrullus lanatus (Thunb.) Matsum. \& Nakai] é amplamente cultivada no estado de Roraima tanto em região de mata como de cerrado. Em inspeções realizadas de maio a setembro de 2003 nos municípios de Boa Vista, Normandia e Pacaraima foram observadas, com freqüência, plantas apresentando manchas foliares, circulares, de coloração pardo-acinzentadas, com dimensões variando de 1 a 5 mm de diâmetro (Figura 1). Em observações feitas em microscópio verificou-se conidióforos amarronzados, em fascículos, com dois a três septos e dimensões de 44-115 x 2,6-5,2 $\mu \mathrm{m}$. Conídios filiformes, hialinos, com seis a 12 septos, $65-170 \mu \mathrm{m}$ de comprimento, 2,6-3,1 $\mu \mathrm{m}$ de largura da base e largura mediana de 2,6 $\mu \mathrm{m}$. As características encontradas permitiram identificar o agente causal como Cercospora citrullina Cooke (Chupp, A monograph of the fungus genus Cercospora, 1954; Hino \& Tokeshi, Some pathogens of cercosporiosis collected in Brazil, 1978). O fungo foi isolado em meio BDA observando-se colônias róseo-arroxeadas com difusão de um pigmento amarelado. Para testes de patogenicidade o fungo foi crescido em meio V-8 ${ }^{\circledR}$ a $27^{\circ} \mathrm{C}$ por 30 dias, em escuro contínuo, preparandose uma suspensão de $10^{5}$ conídios. $\mathrm{ml}^{-1}$. Plantas de melancia cv. Charleston Gray foram inoculadas pulverizando-se a suspensão nas folhas e mantidas em câmara úmida por $12 \mathrm{~h}$. Após sete dias, sintomas típicos da doença foram observados e o patógeno reisolado. Este é o primeiro relato de $C$. citrullina no estado de Roraima, sendo a mancha-decercospora a doença fúngica mais freqüentemente observada na cultura da melancia no estado.

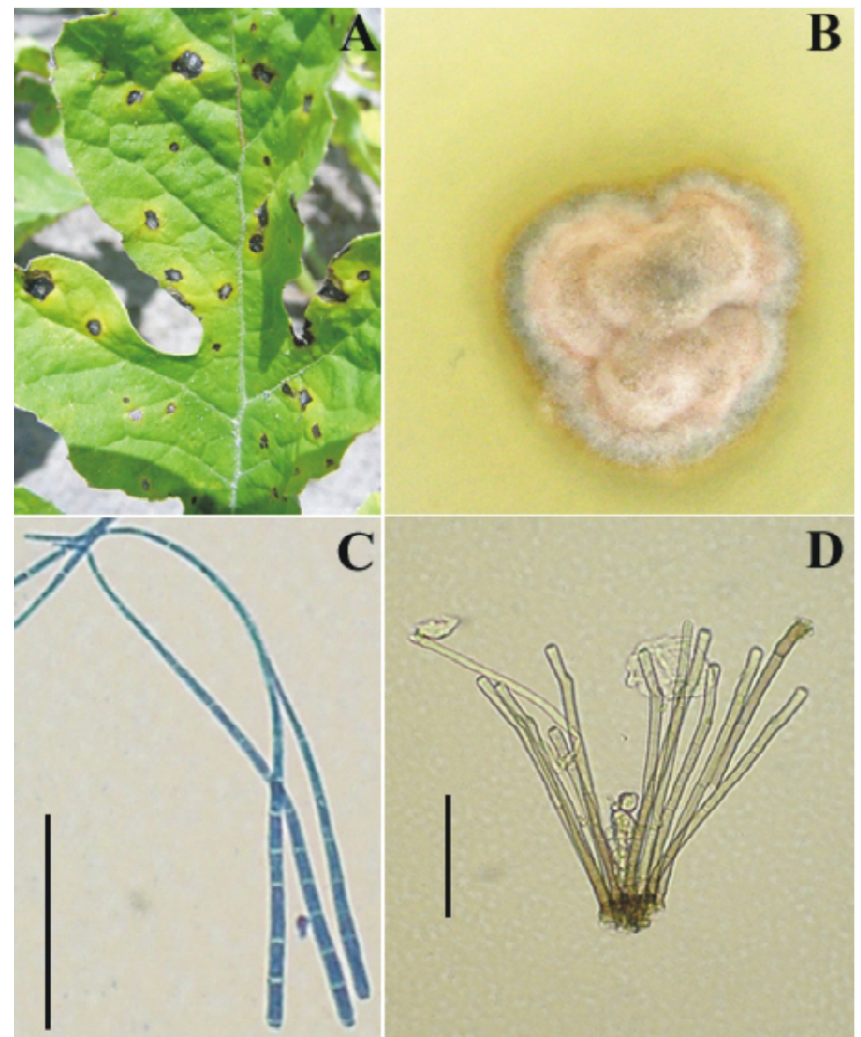

FIG. 1 - A) Sintomas da mancha-de-cercospora em melancia (Citrullus lanatus); B) Colônia de Cercospora citrullina em meio BDA; C) Conídios de C. citrullina; D) Conidióforos de C. citrullina. (barra $=50 \mu \mathrm{m})$. 